\title{
Female Labour Force Status and Fertility Behaviour-Some Theoretical, Methodological and Policy Issues
}

\author{
RAFiQUl Huda ChaUdhurY*
}

\section{INTRODUCTION}

The status of women and their role in community and family decision-making, including timing and number of births and choice of contraception, have an important bearing on improving the standard of living, success of family planning and longterm reduction in fertility of a country. In a society, whose women depend on their children for social and economic security and lack legitimate alternatives to childbearing, fertility is likely to be high. Mandelbaum [34] summarised a number of studies relating to fertility and motivation in Indian society. The most commonly reported reason for desiring large families was the absence of alternative roles for women to the role of wife-mother. This absence of alternative roles for women has often been suggested as a stumbling block to diffusion of small family size norm in developing countries $[56 ; 37]$. For effective reduction of population growth, the proponents of the 'beyond family planning approach' emphasize the complementarity of the roles of men and women, creation of alternatives to childbearing and reduction of dependence on children by providing educational opportunity and economic independence for women $[56 ; 2 ; 3 ; 15 ; 28]$. Of particular interest is the nature of relationship between female education, labour force participation and conjugal role of women on the one hand and fertility and the use of contraception on the other. In this study, an attempt is made to examine the dynamics of the relationship between female labour force status and fertility behaviour (i.e. use of contraception and fertility) and also to evaluate the implication of the relationship for reduction of fertility, particularly with reference to the developing countries of the world.

*The author is a Senior Research Demographer at Bangladesh Institute of Development Studies. The author expresses his thanks to the Co-Editor and an anonymous referee of The Pakistan Development Review for their comments on an earlier draft of this paper. The author is also thankful to Dr. Helen Ware, Research Fellow, in the Department of Demography, Australian National University, for her comments and editing of the manuscript. 


\section{FEMALE LABOUR FORCE STATUS AND FERTILITY BEHAVIOUR}

Female participation in the labour force has often been considered one of the means to promote use of contraception and thereby to reduce fertility. This hypothesis is based on the following assumptions:

(i) employment outside the home provides alternative satisfactions to children such as companionship, recreation, stimulation, creative activity and social and economic rewards. These alternative activities for working women may compete with their raising of children $[1 ; 2 ; 12 ; 25 ; 28 ; 30]$;

(ii) work outside the home delays marriage and also increases the probability of non-marriage for some women because of enhanced economic selfsufficiency $[10 ; 17 ; 56]$. Raising the age at marriage and the proportion remaining single have a depressing effect on fertility;

(iii) every additional child increases the 'opportunity cost' of a working mother in terms of the income forgone by her because of her having to stay at home to raise children. This 'indirect cost' or 'opportunity cost' has a negative bearing on the decision of a working wife to have an additional child [2];

(iv) a working wife, being an earning member of the family, improves her status and finds a greater opportunity to participate in family decisionmaking, and this also facilitates husband-wife communication. Various studies have shown that the higher the joint husband-wife participation in family decision-making the greater the use of contraception and the lower the fertility $[11 ; 19 ; 37 ; 44 ; 57]$; and

(v) working women by attaining economic independence do not have to depend on their children for economic ${ }^{1}$ security in old age.

On the basis of the above assumptions, it is hypothesized that female participation in labour force will be inversely related to fertility and positively related to the use of contraception. Convinced of the plausibility of the work-fertility hypothesis, many population scientists have advocated wider female labour force participation as a means of reduction of fertility, particularly for the developing countries of the world. This concern is well expressed in the following words: 'Policies expressly related to family roles, and opportunities for legitimate alternative satisfaction and activities constitute the crux of future reduction in family size because they directly assault the motivational framework of reproduction' [2], and $\therefore$. better employment prospects and enhanced status in a changing society may be a sufficient condition for fertility reduction ... [6]. However, the relationship between work status of a woman and fertility is very complex and the empirical findings are inconclusive $[20 ; 35 ; 47 ; 22 ; 36 ; 23 ; 8 ; 49 ; 28 ; 57]$. These inconclusive findings are partly due to differences in study designs, sources of data, and the

${ }^{1}$ Dependence on children as an old-age security is a more important issue in developing countries than in developed countries. various measurement instruments and partly due to complexities in the relationship between labour force participation and fertility. Here, we have tried to address ourselves to a few of these complexities both (a) Theoretical and (b) Methodological.

\section{THEORETICAL COMPLEXITIES}

Female labour force participation per se does not determine fertility behaviour for the effect of work on fertility is itself dependent on such factors as (i) the setting of work; (ii) the type of work; (iii) the motivation for working; (iv) role incompatibility; (v) work commitment; (vi) duration of work; (vii) child-care facilities; (viii) type of family; and (ix) the life-cycle stage. How each of the above factors interacts with the relationship between work status and fertility is discussed below.

\section{Setting of Work and Fertility}

It is often found that the fertility of unpaid family workers engaged in cottage industries or of women engaged in agricultural activities in the rural areas is higher than, or does not differ significantly from, the fertility of non-working women. But women working in the modernized sector of the economy in urban areas, particularly in big metropolises and industrial cities, have lower fertility than their non-working counterparts $[22 ; 23 ; 49 ; 50 ; 26 ; 45]$. The failure to find a smaller number of children among women working in cottage industries or on family farms in rural areas may be due to the fact that the roles of such working females as women are not incompatible with their role as mothers because they do not work completely outside the environment of home and, therefore, can combine their productive activities with child-rearing. Moreover, those who work in family enterprises may receive support from their parents or other family surrogates in raising young children and looking after other domestic chores. Child-rearing is not, therefore, a constraint for this group of women. Participation in the modernized sector of the economy in urban areas calls for greater separation of work from home. Moreover, availability of support from parents and relatives is also rarer in urban areas. Therefore, role incompatibility is greater among women working in the modern sector of the economy in the urban areas than among those women who work'in the traditional sector of the economy, like cottage industries, trading in village markets and family farm in rural areas.

This variation in role incompatibility may explain the lower fertility of those women who work in the modern sector of the economy in the urban areas and the higher fertility among those women who work in the traditional sector of the economy. However, there may be other important factors explaining the difference in the fertility of the above two groups of working women. For example, social and economic aspirations, attitudes and education background of the women working in 
the modern sector of the economy in the urban areas may be different from those of the women working in the traditional sector of the economy in the rural areas. Urban centres are considered the citadel of new ideas while rural areas are bound by tradition. Therefore, it is not only the higher role incompatibility of urban working women which induces them to lower their fertility but their attitudes, social and economic aspirations and educational background may be equally important factors in the dynamics of work/fertility relationship in the urban and rural sectors of the economy which needs to be further investigated.

From the above discussions, one may draw the following tentative conclusions: that there would be an inverse relationship between work status and fertility in the modern sector of the economy but the relationship may be either positive or nonexistent in the case of participation in the traditional sectors of the economy. However, female participation in the modernized sector of the economy does not necessarily lead to greater use of contraception and lower fertility, particularly in situations where a working woman lacks commitment to work [48], belongs to an extended family $[5 ; 39 ; 49 ; 50]$, and originates from a poor socio-economic background $[11 ; 29 ; 59]$. Work/fertility relationship in each of the above situations will be discussed elaborately below.

\section{Work Commitment and Fertility}

The relationship between work status and fertility varies with the degree of work commitment. Among a section of urban Greek working women, Rothschild [48] found that fertility and use of contraception of working women with low work commitment, participating in the modern sector of the economy, did not differ from those of women who did not work. But women with high work commitment had lower fertility and used contraception more frequently in comparison with those women who worked with low work commitment or had not worked. However, the degree of commitment to work varied with education and occupation. (A detailed discussion of interaction among degree of work commitment, education and occupation and their effect on fertility is outlined below in the section on "Work Status, Social Class and Fertility".)

\section{Work, Family Type and Fertility}

Relationship between participation in the modernized sector of the economy and fertility may also vary with family type. The relationship between work status and fertility is usually found to be inverse in the nuclear families but positive in extended families $[5 ; 39 ; 49 ; 50]$. This may be because

(i) there are adult relatives in extended families, who can look after children and other domestic chores so that working women belonging to extended families may not find a major constraint on combining their productive role with their child-bearing role; but child-care responsibilities in nuclear families are mainly of the mother and therefore a working woman belonging to a nuclear family may find it difficult to combine the roles of mother and worker;

(ii) the work commitment of the female workers living in extended families may have little consequence for their family size, as they may have been motivated to work outside the home in order to escape the tensions and conflicts arising from living in extended families; and

(iii) women belonging to extended families may be under pressure from parents-in-law to produce more children. In a traditional extended family system, the status of a daughter-in-law is subordinate to her mother-in-law and/or other elder members of the family.

In the above set-up, the young bride has very little independent role in fertility decision. This lack of independent control over fertility decision and submission to parental control on the part of the young bride is considered to be one of the reasons for higher fertility in extended families because parents want to enforce traditional high fertility norm for various economic and non-economic reasons $[14 ; 51 ; 33 ; 4$; $41 ; 52]$. But couples in nuclear families have fewer obligations to their original lineages and also have fewer expectations from them and therefore they are under less pressure to oblige the expectation of the high fertility norm prevailing in the traditional extended families and are relatively more free to choose their own family size.

However, these explanations are not sufficient to convince one that fertility of working women would be always higher in extended families and lower in nuclear families. There may be circumstances in which a working woman belonging to nuclear family may have higher fertility if she has grown-up children and/or easily available domestic servants to look after the young children, as is often the case for middle-class women in developing countries [9]. Therefore, the relationship between work status and fertility by family type should be studied after controlling other intervening variables which may have affected the above relationship. Attempts should also be made to dissect the fertility of working and non-working women by family type.

\section{Work, Economic Independence and Fertility}

The findings of a positive or no relationship between work status and fertility among unpaid family workers in cottage industries and family farm do not necessarily prove that the effect of work on fertility is either positive or zero in the traditional sector of the economy. The observed relationships in the traditional sector of the economy may have arisen out of the absence of payment or the lack of economic independence of the unpaid family labourers. If women were paid for their work, they would have possibly produced fewer children. An example of this may be 
found in the case of the People's Republic of China where women work in the traditional sector of the economy, viz. agriculture, but they are paid equally with men for the same kind of work and have relatively small numbers of children [55]. In the Chinese system, since the wage is directly paid to the labourer, women receive compensation for their labour, can depend on themselves for food and clothing, and, for other economic necessities, do not have to depend on their husbands. This economic independence of the married woman also raises her status in the family and her opportunity to participate in family decision-making. Women in China, along with men, also participate in community decision-making, including family planning, and timing and number of children [27]. The economic independence of a married woman and her participation in community and family decision-making including timing and number of births, may have played a significant role in the decline of Chinese fertility. However, female emancipation in China is tied up with profound social and political changes. Therefore, the effect of economic independence of women on fertility is difficult to isolate from the effect of ideological and organizational changes on fertility decline in China. The social and political changes which took place in China may be difficult to achieve in other developing countries without major institutional changes.

\section{Work Status, Social Class and Fertility}

The relationship between work status and fertility also varies with the type of occupation and social class. Lower fertility is more pronounced among the higher occupation and education groups than among lower occupation (blue collar/traditional) and education groups $[29 ; 59]$. This differential relationship between work status and fertility by social class, i.e. occupation and education group, is usually attributed to variation in (i) motivation to work; (ii) work commitment; and (iii) role incompatibility. Perceived role conflict is expected to be more prominent among the higher occupation and education groups than among lower occupation and education groups because work commitment, and social and economic rewards are expected to be higher among the former groups than among the latter groups. Women belonging to higher occupation and education groups usually originate from higher income families and they accept jobs outside the home of their own volition unlike those women belonging to lower occupation and education groups who accept job mainly because of economic necessity, as they belong to poor income families. ${ }^{2}$

${ }^{2}$ The acceptance of job because of economic necessity may also be true of higher occupation or education groups. But economic need, as a reason for joining labour force outside the home, may be less compelling among women originating from higher occupation or education groups than among those originating from lower occupation or education groups. This has also been supported by data. Chaudhury [9], employing data collected in the course of a socioeconomic survey of working versus non-working women of metropolitan Dacca (Capital of Bangladesh), found that those women who claimed to be woking out of need disproportionately came from poor families than women who said they worked for other reasons.
Women who work mainly for economic necessities may find work outside the home an undesirable obstacle to spending time with children and therefore it may not be inconvenient for them to combine the roles of a mother and a worker. A recent UN report on the status of women and family planning maintains that if employment is economically essential and if the rewards for work are not sufficiently attractive, women may more readily sacrifice their jobs in order to bear and raise children than forgo child-bearing [56].

The 'opportunity cost' of having an additional child is likely to be higher among working women belonging to upper echelon of occupation and education hierarchy in comparison to those women belonging to lower occupation and education groups since the former derive greater economic and social benefit out of work than the latter. ${ }^{3}$ However, 'opportunity cost' of having an additional child may not necessarily be higher in the upper social class. It may vary from individual to individual. A woman even belonging to lower occupation and social class might have a higher 'opportunity cost' if she is working out of sheer necessity and is adding the needed money to her family income than a woman of a higher occupation group who is working out of her own volition. Therefore, economic necessities may also compel a woman to work and restrict her fertility.

From the preceding findings and interpretations, it appears that if women's employment is to affect fertility significantly, it must be socially valued and rewarded as highly as child-bearing. When a job is creative and demand skills that are achieved at high cost and provide women sufficient salary and a status equal to that of men, women may develop a career orientation and commitment to work. Because of the career orientation they may like to have smaller families and even to space their children at longer intervals.

The findings of the negative effect of non-familial activities on fertility among higher socio-economic groups are not conclusive. There are some other studies which show greater effect of work status on fertility among women of lower socioeconomic status than among those of higher socio-economic status $[11 ; 32 ; 53]$.

${ }^{3} \mathrm{~A}$ highly educated woman has a much higher 'opportunity cost' (i.e. earnings that the woman might have had, but had to forgo because of the need to care for her children) for the following reasons: (i) she gives up more working time since the better educated she is the more likely she is to be working; and (ii) she sacrifices higher wages by having a child. This is also demonstrated in a study by Espenshade [18]. Espenshade, employing data of the U.S.A., estimated how much the first child would cost to mothers, having varying levels of education, in lost earnings over the first 15 years of that child's life. According to the above estimate, 'opportunity cost' increases as the level of education goes up. For example, estimated 'opportunity cost' rises from $\$ 26,562$ for wives with only an elementary school education to $\$ 54,347$ for those who have attained University education. An earlier study in the U. S. A. also confirmed the positive relationship between level of education and 'opportunity cost' in having a child [42]. However, a little caution is necessary: although there exists a positive relationship between level of education and 'opportunity cost' in having a child, its magnitude may vary from country to country, depending on, among other factors, the level of economic development of a country, the life style of the people, etc. 
For example, Chaudhury $[7 ; 10]$ has examined the relationship between female labour force status and fertility by employing data collected in the course of a socioeconomic survey of working versus non-working women in 1974. The working women were defined as those women who had been gainfully occupied outside their home and non-working women were those who had never been gainfully employed outside the home but had the same general level of education as those of working women. There were 582 working and 548 non-working women all of whom were currently married, living with their husbands and reported to be fecund. Analysing the data, Chaudhury found no variation in fertility and the use of contraception by work status at higher levels of education but fertility and the use of contraception were found to vary with work status at the lower levels of education. A working woman who is illiterate or who has only had limited formal education has fewer children and uses contraception more frequently than her counterpart who is not working. But at higher education levels, women have fewer children and practise contraception more frequently irrespective of whether they are working outside the home or not. Utilizing the same data, Chaudhury examined the differences in the use of contraception between working and non-working women by income of husband. He found no difference in the use of contraception between working and non-working women in the higher income categories, although the use of contraception varies by work status in the lower income categories. The above findings have led some to believe that if work is to affect fertility behaviour, it is more likely to reduce the fertility of those women who belong to lower socio-economic group than of those who are in the higher socio-economic group because work outside the home possibly provides the only alternative satisfaction to children for the former group but work is only one of the several other alternative satisfactions to children for the latter group. From the above findings and interpretations, one may also tend to hypothesize that given employment opportunities outside the home, reduction in fertility is also possible among women of lower socio-economic status.

\section{Duration of Work and Fertility}

The negative effect of work on fertility also depends on the duration of work. It is plausible to argue that a woman who works for a larger proportion of her reproductive life is likely to develop more interests in extra-familial activities or become more career-oriented than a woman who works for a brief period of time. Moreover, market earning potential of a working woman rises with her work experience [46]. This hypothesis is also confirmed by data drawn from different countries $[11 ; 32 ; 43 ; 59]$. However, an exception to this hypothesis may arise in a situation where a woman joins labour force after having several births.

\section{Effect of Provisions for Maternity Leave}

and Child-care Facilities on Fertility

Whether the provisions of maternity leave with full salary and child-care facilities to working women will attenuate the effect of work on fertility is a subject of considerable debate. Some argue that allowing working women maternity leave with full salary and subsidized child-care facilities will stimulate fertility by reducing the cost of children to the parents. To the knowledge of the author there are no studies which have ever attempted to evaluate the impact of availability of maternity leave with full salary and subsidized child-care facilities on fertility. But on a prima facie basis, we may say that the above provisions are not necessarily pro-natalist as the experience of the socialist countries suggests. We may, however, sound one note of caution here. Provisions whereby mothers are paid to stay at home to nurse children may well be pro-natalist in nature. The recent measures in Hungary and Czechoslovakia, which effectively pay women to stay at home to bring up their children themselves, have been associated with a noticeable impact of fertility in those countries $[21 ; 24]$. The experience of socialist countries suggests that policy measures which reduce the cost of children to couples by providing cheap childcare will have a depressing effect on fertility levels as compared with policy measures which reduce the cost equivalently but enable parents to bring up their children themselves.

But this may not be true in the context of many developing countries. For example, in developing countries like Bangladesh, India and Pakistan, there exist provisions of maternity leave with full salary, particularly for those women who are engaged in the formal sector of the economy. In these countries, cheap non-institutionalized child-care facilities are also available. Under the circumstances, introduction of child-care facilities may further relax the constraints of having higher number of children. However, the effect of these provisions on fertility in developing countries is not likely to be very significant since the majority of working women in these countries are self-employed and engaged in home-based traditional sector of the economy. These are empirical issues and need further rigorous scientific investigation.

\section{Effect of Work on Fertility by Life Cycle}

It is often found that in the younger ages $(<30)$, the fertility of women in the labour force is lower than of the non-working women, but in the older ages, the effect of work on fertility is either positive or zero $[23 ; 32 ; 47]$. The above finding may signify that non-familial participation has only a temporary effect upon fertility, resulting from different patterns of child-spacing and age at marriage, rather than having a permanent effect upon completed family size 


\section{Relationship Between Historical Decline in Fertility} and Female Participation in Labour Force

Last, but not the least, one may be very much tempted to ask whether it is necessary that a country must employ a certain proportion of its female population in the non-agricultural labour force in order to induce an appreciable decline in the fertility of that country? The answer is probably no, as one finds that an appreciable decline in fertility took place in the West and North Europe in the 19th Century without a significant female participation in non-agricultural activities. Female participation in non-agricultural activities as a necessary pre-condition for inducing an appreciable decline in fertility is also contradicted by the findings of Demeny [16] who reports a trend of raising one-child families in the rural areas of Hungary in the 18 th Century.

In addition to the above-mentioned theoretical issues regarding work/fertility hypothesis, there still remain many thorny methodological issues in explaining the relationship between work status and fertility. These methodological issues are discussed below.

\section{METHODOLOGICAL ISSUES}

\section{Fecundity Status}

It is often found that the working women have a higher incidence of fecundity impairment than non-working women $[20 ; 48]$, and this differential fecundity status may in part account for differential fertility between working and non-working women. Thus, fecundity status has to be duly considered while examining the relationship between female labour force status and fertility.

\section{Is it Work That Affects Fertility or Fertility That Affects Work?}

A question may be raised whether it is work that causes working women to have fewer children or whether they work because they have fewer children? Similarly, work experience is often found to be positively associated with spacing. But the question is: Why is this so? Is it because some women work for a longer time because their children are born at longer intervals or is it that they space children at longer intervals in order to be able to work? The relationship can operate in both directions. This cause-and-effect problem has to be resolved while examining the relationship between work status and fertility.

\section{Recruitment Bias/Work Conditions}

It is often alleged that employment agencies or employers prefer to recruit women who have relatively few children and discourage pregnancy and/or adopt punitive measures against working women having babies while in employment. Under these conditions, a working woman is likely to have fewer children than a non-working woman. The net effect of work on fertility cannot, therefore, be isolated.

\section{Temporal Alignment}

Sometimes, a wife's current labour force status is related to her cumulated fertility, which is a measure of past events. But this is misleading and can also produce a distorted picture. To avoid this problem, the measures of labour force participation and fertility have to be aligned in time.

\section{Motives for Non-Working Women}

Why do some women not work? Is it because thay have too many children? Or, is it that their pregnancies have followed one another so quickly that they have been prevented from working when they would have actually preferred to enter into labour force? Or, is there a lack of adequate employment? Or, is it they prefer large families or home-making to employment? There is a need to examine the above issues, to help understand the dynamics of relationship between work status and fertility.

\section{Net Effect of Work on Fertility}

Does female participation in labour force independently lead to lower fertility or is the relationship due to some other antecedent variables? Female labour force participation and fertility are related to several antecedent variables such as age, education, duration of marriage, husband-wife role relationship, fecundity, availability of contraception, etc. Therefore, to examine the net relationship between female labour force participation and fertility, we need to control for those variables which are related to both independent (labour force participation) and dependent variables (fertility). Few studies have controlled for all variations of these intervening variables to examine the net effect of female work status on fertility and their findings are inconclusive $[11 ; 25 ; 28 ; 44 ; 54]$. This means that the independent effect of work on fertility has yet to be proved conclusively.

\section{OVERVIEW}

Although the relationship between female labour force participation and fertility remains highly complex, it would still not be wild to hypothesize that given employment opportunities outside the home, a working woman will have fewer children and use contraception more frequently if she (i) is paid for her work and finds her labour treated as equally valuable with a man's labour; (ii) has the oppor- 
tunity to participate in community and family decision-making in broad areas, including the number of children; (iii) is committed to her work; (iv) finds it difficult to transfer child-care responsibilities to others; and (v) works for a long period of time before having many children.

There is certainly some merit in providing females with employment opportunities outside the home as a policy move towards reduction of fertility. Although female participation in labour force may not be a necessary pre-condition for reduction of fertility, employment opportunities outside the home will create an environment for self-expression for women other than through being wives and mothers. Moreover, women exposed to non-familial activities, interests and rewards over a long period of time may reduce their desire for additional children. However, there is a need for further research to delineate more precisely the casual mechanisms through which female work affects fertility behaviour and the cause-and-effect dynamics of work/fertility relationship.

\section{POLICY ISSUES}

For females in the developing countries of the world, there are relatively few employment opportunities outside the home [56]. Moreover, male attitudes towards female employment outside home are also often negative [10]. It is commonly maintained in developing societies that in a situation where there is a large pool of unemployed and underemployed men, the question of providing jobs to females is a redundant issue. But this is a negative approach. As a fundamental right, women should have equal access to employment opportunities with men. In order to avoid competition with men, policies may be adopted to recruit women, particularly in those sectors which were traditionally served by women, for example, health, education, family planning, etc. Cottage industries, dairy farming, poultry farming, horticulture and like occupations may provide gainful employment opportunities to illiterate women as well as to those who have only few years of schooling. Employment and education in the long run must provide alternatives to child-bearing; in the short run, increasing, even slightly, the economic status of women (through simple innovations and training that increase their productivity) may do much to broaden their views which may result in a greater use of contraception and reduced family sizes.

In order to promote female education and employment, there is a need for a persistent drive against those social customs, beliefs and traditions which undermine the value of women as compared to men. Efforts should be made to dismantle the belief that women are inferior to men, and motherhood and domestic activities are the only desirable role for a woman.

Advocates of family planning programmes often argue that reduction in fertility would allow women to pursue higher education and gainful employment for attain- ing higher social status. But it can be equally forcibly argued that women who have attained higher status in terms of higher education, involvement in family decisionmaking, gainful employment outside the home and higher age at marriage for whatever reasons would also wish to practise contraception. Consequently, the issue of enhancing female status appears to be of crucial importance in creating an environment in which women would want to practise contraception in order to reduce fertility.

\section{RESEARCH NEEDS}

Further research is needed to (i) identify types of occupations and education facilities that can be generated in the rural areas of developing countries to divert the attention of women from normative pressure to get married early and have a large family; (ii) examine the cost of these facilities; and (iii) determine how these activities should be related to other rural development programmes, such as decentralization of industries to rural areas. Polgar [40] has suggested the need to study some of the actual situations in order to answer these questions. For example, where industrialization has been going on in some rural areas, attempts should be made to examine the impact of such rural industrialization programmes on women's employment, age at marriage, and attitudes toward contraception and fertility. Another research need pointed out by Muthia and Sastry [38] is the exploration of the nature of social change that is taking place within the family or the kinship system in a given area which may encourage women to accept employment outside the home. For example, a change in family structure, from the extended to the nuclear type, may have slackened the authority of kin, particularly of the in-laws. This changed situation may have created opportunities for female participation in labour force outside the home. It would be also interesting to examine how and in what way the status and influence of employed women under the changed circumstances differ from those in areas where such changes did not take place.

\section{REFERENCES}

1. Berelson, Bernard. "Beyond Family Planning". Studies in Family Planning. Vol. 38, No. 2. February 1969.

2. Blake, Judith. "Demographic Science and the Redirection of Population Policy". In M. C. Sheps and J. C. Ridley (eds.), Public Health and Population Change: Current Research Issues. Pittsburgh: University of Pittsburgh Press. 1965. pp. 41-69.

3. Blake, Judith. "Are Babies Consumer Durables? A Critique of the Economic Theory of Reproductive Motivations". Population Studies. Vol. 22, No. 1. May 1968. 
4. Burch, T. K., and Murray Gendell. "Extended Family Structure and Fertility: Some Conceptual and Methodological Issues". Journal of Marriage and the Family. Vol. 32, No. 2. May 1970.

5. Carleton, Robert O. "Labour Force Participation: A Stimulus to Fertility in Puerto Rico". Demography. Vol. 2, No. 1. 1965.

6. Cassen, Robert H. "Population and Development: A Survey". World Development. Vol. 4, No. 10/11. 1976.

7. Chaudhury, Rafiqul H. "Education and Fertility in Bangladesh". The Bangladesh Development Studies. Vol. V, No. 1. January 1977.

8. Chaudhury, Rafiqul H. "Labour Force Status and Fertility". The Bangladesh Development Studies. Vol. II, No. 4. 1974.

9. Chaudhury, Rafiqul H. "Marriage, Urban Women, and the Labour Force: The Bangladesh Case”. SIGNS. Vol. 5, No. 2. Autumn 1979.

10. Chaudhury, Rafiqul H. "Married Women in Non-agricultural Occupations in a Metropolitan Urban Area of Bangladesh - Some Issues and Problems". The Bangladesh Developmènt Studies. Vol. V, No. 2. April 1977.

11. Chaudhury, Rafiqul H. "Socio-cultural Factors Affecting Practice of Contraception in a Metropolitan Urban Area of Bangladesh". Paper presented at the seminar on " Fertility in Bangladesh - Which way is it moving?" held at Cox's Bażar on December 21-23, 1976.

12. Collver, Andrew. "Women's Work Participation and Fertility in Metropolitan Areas". Demography. Vol. 5, No. 1. 1968.

13. Collver, Andrew, and Eleanor Langlois. "The Female Labour Force in Metropolitan Areas: An International Comparison". Economic Development and Cultural Change. Vol. 10, No.4. July 1962.

14. Davis, Kingsley. "Institutional Patterns Favouring High Fertility in Underdeveloped Area". Eugenics Quarterly. Vol. 2, No. 1. March 1955.

15. Davis, Kingsley. "Population Policy: Will Current Programs Succeed?" Science. No. 3802. 10 November, 1967.

16. Demeny, Paul. "Early Fertility Decline in Austria-Hungary: A Lesson in Demographic Transition”. In D. V. Glass and Roger Revelle (eds.), Population and Social Change. London: E. Arnold and Company. 1972.

17. Dube, D. C. et al. Fertility Behaviour of Working and Non-Working Women New Delhi: National Institute of Family Planning. 1974.

18. Espenshade, Thomas. "The Value and Cost of Children". Population Bulletin. Vol. 32, No. 1. April 1977

19. Eugene, Lupri. "Contemporary Authority Patterns in the West German Family A Study in Cross-national Validation". Journal of Marriage and the Family. Vol. 31, No. 1. February 1969.

20. Freedman, R. et al. Family Planning, Sterility and Population Growth. New York: McGraw-Hill Book Company, 1959.
21. Frenkel, I. "Attitudes Towards Family Size in Some East European Countries". Population Studies. Vol. 30, No. 1. March 1976.

22. Gendell, M. et al. "Fertility and Economic Activity of Women in Guatemala City, 1964". Demography. Vol. 7, No. 3. 1970.

23. Goldstein, S. "The Influence of Labour Force Participation and Education on Fertility in Thailand". Population Studies. Vol. 26, No. 3. 1972.

24. Heitlinger, A. "Pro-natalist Population Policies in Czechoslovakia". Population Studies. Vol. 30, No. 1. 1976.

25. Jafee, A. J. People, Jobs and Economic Development. Glenco, Ill: The Free Press. 1959.

26. Jafee, A. J., and K. Azumi. "The Birth Rate and Cottage Industries in Underdeveloped Countries". Economic Development and Cultural Change. Vol. 9, Part I. 1960-61.

27. Kane, Penny. "Population Planning in China: The Individual and the State". In Scarlett T. Epstein and Darrell Jackson (eds.), Feasibility of Fertility Planning. London: Pergamon Press. 1977.

28. Kasarda, J. D. "Economic Structure and Fertility: A Comparative Analysis". Demography. Vol. 8, No. 3. August 1971.

29. Khalifa, A. "The Status of Women in Relation to Fertility and Family Planning in Egypt". Cairo: National Centre for Social and Criminological Research. 1973. (Mimeographed)

30. Kirk, Dudley. "Natality in the Developing Countries: Recent Trends and Prospects”. In S. J. Behrman et al. (eds.), Fertility and Family Planning. Ann Arbor: The University of Michigan Press. 1969.

31. Knodel, John. The Decline of Fertility in Germany, 1871-1939. Princeton, N. J. : Princeton University Press. 1974.

32. Kupinsky, S. "Non-familial Activity and Socio-economic Differentials in Fertility". Demography. Vol. 8, No. 3. 1971.

33. Liebenstein, H. "The Economic Theory of Fertility Decline". Quarterly Journal of Economics. Vol. 89, No.1. February 1975.

34. Mandelbaum, David. Human Fertility in India. Berkeley and Los Angeles: University of California Press. 1974.

35. Mazur, D. P. "Birth Control and Regional Differentials in the Soviet Union". Population Studies. Vol. 22, No. 3. 1968.

36. Morsa, J. "Travail des Femmes et Natalite". Revue de I'Institut de Sociologie. 2. 1959.

37. Mukherjee, Bishwa N. "Status of Women as Related to Family Planning". Journal of Population Research. Vol. 2, No. 1, 1975.

38. Muthia, A., and K. R. Sastry. "Alternative to Values and Benefits Derived from Children and Large Families - A Review". In L. T. Ruzicka (eds.), The Economic and Social Supports for High Fertility. Canberra: Australian National University. 1977. 
39. Peek, Peter. "Family Composition and Married Female Employment: The Case of Chile". ILO: Population and Employment Division. 1975. (Working Paper No. 13)

40. Polgar, S. "A Study Proposal on Occupation Alternatives and Natality Among Rural Women". Chapel Hill: University of North Carolina. n. d.

41. Rainwater, Lee. Family Design: Marital Sexuality, Family Size and Contraception. Chicago: Aldine Publishing Company. 1965.

42. Reed, Ritchie H., and Susan McIntosh. "Costs of Children". In Elliot R. Morss and Ritchie H. Reed (eds.), Economic Aspects of Population Change. Vol. 2. Washington D. C. : Commission on Population Growth and the American Future. 1972.

43. Ridley, Jeane C. "Demographic Change and the Roles and Status of Women". The Annals of the American Academy of Political and Social Science. Vol. 375, No. 1. 1968.

44. Ridley, Jeane C. "Number of Children Expected in Relation to Non-familial Activities of the Wife". Milbank Memorial Fund Quarterly. Vol. 37, No. 3. July 1959.

45. Rosen, B., and A. Simmons. "Industrialization, Family and Fertility: Structuralpsychological Analysis of the Brazilian Case". Demography. Vol. 8, No. 1. 1971.

46. Rosenzweig, Mark R. "Female Work Experience, Employment Status and Birth Expectations: Sequential Decision Making in the Philippines”. Demography. Vol. 13, No. 3. 1976.

47. Rothschild, Safilios. "Socio-psychological Factors Affecting Fertility in Urban Greece: A Preliminary Report”. Journal of Marriage and the Family. Vol. 31, No. 3. August 1969.

48. Rothschild, Safilios. "The Relationship between Work Commitment and Fertility". International Journal of Sociology of the Family. Vol. 2, No. 1. March 1972.

49. Shah, Nasra. "Female Labour Force Participation and Fertility Desires in Pakistan: An Empirical Investigation". Pakistan Development Review. Vol. XIV, No. 2. Summer 1975.

50. Shah, Nasra. "Work Participation of Currently Married Women in Pakistan: Influence of Socio-economic and Demographic Factors". Pakistan Development Review. Vol. XIV, No. 4. Winter 1975.

51. Shalins, M. D. "Land Use and the Extended Family in Modern Fiji". In Andrew P. Vayda (ed.), Environment and Cultural Behaviour: Ecological Studies in Cultural Anthropology. Garden City: Natural History Press. 1969.

52. Strauss, M. A. "Social Class, Fertility and Authority in Nuclear and Joint Households in Bombay". Journal of Asia and African Studies. Vol. 4, No. 1. January 1969.
53. Stycos, Mayone J. "Female Working Roles and Fertility". Demography. Vol. 4, No. 1. 1967

54. Terry, Gereldine B. "Rival Explanations in the Work-fertility Relations". Population Studies. Vol. 29, No. 2. July 1975.

55. Tien, Yuan H. "Employment and Education of Women in China: Implications for Fertility Change". International Population Conference. London 1969. Vol. III. Liege: International Union for the Scientific Study of the Population. 1971.

56. United Nations. Department of Economic and Social Affairs. Status of Women and Family Planning. New York: United Nations. 1975. E/CN. 6/575/Rev.

57. Weller, R. H. "Role Conflict and Fertility". Social and Economic Studies (Jamaica). Vol. 18, No. 3. September 1969.

58. Weller, R. H., and James M. Sakoda. "A Longitudinal Study of Female Employment and Fertility in Puerto Rico, 1940-1960”. Paper presented at the Annual Meeting of the Eastern Sociological Society, New York. April 1971.

59. Westoff, Charles F. et al. The Third Child: A Study in the Prediction of Fertility. Princeton, N. J.: Princeton University Press. 1963 